\title{
Concentrations of Heavy Metals in Six Municipal Sludges from Guangzhou and Their Potential Ecological Risk Assessment for Agricultural Land Use
}

\author{
Jingyong Liu ${ }^{1 *}$, Zhongxu Zhuo ${ }^{1}$, Shuiyu Sun ${ }^{1}$, Xunan Ning', Suying Zhao', \\ Wuming Xie ${ }^{1}$, Yujie Wang ${ }^{1}$, Li Zheng ${ }^{1}$, Rong Huang ${ }^{3}$, Bing $\mathbf{L i}^{4}$ \\ ${ }^{1}$ School of Environmental Science and Engineering, Guangdong University of Technology, Guangzhou 510006, China \\ ${ }^{2}$ China Environment Technology (HK) Limited, HK, 999077, China \\ ${ }^{3}$ School of Management, Guangdong University of Technology, Guangzhou 510520, China \\ ${ }^{4}$ Dongguan Chao Ying Textile Co., Ltd., Dongguan, 523147, China
}

Received: 8 April 2014

Accepted: 3 August 2014

\begin{abstract}
Six kinds of municipal sludge samples were collected from wastewater treatment plants (WWTPs) from Guangzhou in southern China. Total concentration of $\mathrm{Cu}, \mathrm{Pb}, \mathrm{Zn}, \mathrm{Cr}, \mathrm{Ni}, \mathrm{Cd}$, and $\mathrm{Mn}$ in the sludge was determined, and used obtained values to appraise the degree of agricultural land pollution on the base of four pollution indixes. Results showed that the concentrations of the heavy metals $\mathrm{Cu}(4.567 \mathrm{mg} / \mathrm{kg}), \mathrm{Mn}(1.844$ $\mathrm{mg} / \mathrm{kg}), \mathrm{Ni}(148 \mathrm{mg} / \mathrm{kg}), \mathrm{Cr}(121 \mathrm{mg} / \mathrm{kg})$, and Cd $(5.99 \mathrm{mg} / \mathrm{kg})$ in S1 sludge were higher than that of the other sludges. In six sludge samples the concentrations of $\mathrm{Mn}, \mathrm{Zn}$, and $\mathrm{Cu}$ were highest, followed by $\mathrm{Ni}, \mathrm{Pb}$, and $\mathrm{Cr}$. $\mathrm{Cd}$ had the lowest concentration. All were higher than those recorded in the background data for crop soils. With the exception of $\mathrm{Cu}$ and $\mathrm{Cd}$ from site $\mathrm{S} 1$, and Ni from sites S1, S2, and S5, all other metal concentrations conformed to permissible levels prescribed by the national application standard of acid soil in China (GB18918-2002). The geoaccumulation index $\left(I_{\text {geo }}\right)$ assessment results indicate that there are serious risks in agricultural utilization for the existing $\mathrm{Cu}$ and $\mathrm{Zn}$ in these six kinds of sludges, especially the $I_{\text {geo }}$, which was 6.53 for $\mathrm{Cu}, 3.21$ for $\mathrm{Mn}, 2.78$ for $\mathrm{Cd}$ in the $\mathrm{S} 1$ sludge. The results of $R I$ showed that sludge had high potential ecological risks, especially caused by $\mathrm{Cd}$, which should give rise to widespread concerns. The potential ecological risk index $(R I)$ of heavy metals in six sludge samples was ranked in the order of $\mathrm{S} 1>\mathrm{S} 2>\mathrm{S} 4>\mathrm{S} 3>\mathrm{S} 5>\mathrm{S} 6$.
\end{abstract}

Keywords: municipal sludge, heavy metal, geoaccumulation index $\left(I_{\text {geo }}\right)$, potential ecological risk index $(R I)$

\section{Introduction}

The increasing numbers of plants for the treatment of wastewater have brought about an increase in the genera-

*e-mail: www053991@126.com tion of sewage sludge [1]. Large volumes of sludge need to be disposed of or treated in some manner. One way of sludge disposal is its application on land, and this has become common practice [2]. The application of sewage sludge on agricultural soils has been widespread in many countries around the world and this has been shown to 
Table 1. Descriptive data of the selected municipal and industrial wastewater treatment plants.

\begin{tabular}{|c|c|c|c|c|c|c|}
\hline $\begin{array}{c}\text { Name of } \\
\text { WWTP }\end{array}$ & No. & $\begin{array}{c}\text { Treatment scale } \\
\left(\mathrm{m}^{3} / \mathrm{d}\right)\end{array}$ & $\begin{array}{c}\text { Population } \\
\text { equivalents }\end{array}$ & Treatment process & $\begin{array}{c}\text { Disposal and use } \\
\text { of sludge }\end{array}$ & Proportion $^{\mathrm{a})}$ \\
\hline KFQ & $\mathrm{S} 1$ & $3.0 \times 10^{4}$ & $6.0 \times 10^{4}$ & Activated sludge & Landfill & $70 \%$ \\
\hline DTS & S2 & $60.66 \times 10^{4}$ & $142.7 \times 10^{4}$ & Activated sludge & Sanitary landfill & $40 \%$ \\
\hline LJ & S3 & $40.0 \times 10^{4}$ & $134.3 \times 10^{4}$ & Anaeroxic-Anoxic-Oxic $\left(\mathrm{A}^{2} / \mathrm{O}\right)$ & Building materials & $<5 \%$ \\
\hline LD & S4 & $103.67 \times 10^{4}$ & $225.8 \times 10^{4}$ & Alternating activated sludge & Building materials & $<5 \%$ \\
\hline ZZ & S5 & $/$ & $/$ & $\mathrm{A}^{2} / \mathrm{O}-$ Aeration ditch & Sanitary landfill & $100 \%$ \\
\hline ZQ & S6 & $4.0 \times 10^{4}$ & $18.6 \times 10^{4}$ & $\begin{array}{c}\text { Microporous aeration }- \\
\text { Carrousel } 2000 \text { oxidation ditch process }\end{array}$ & Building materials & $<5 \%$ \\
\hline
\end{tabular}

a) Proportion: The mass of industrial wastewater/Total mass effluents $\times 100 \%$

improve soil properties and increase plant productivity [3]. In the European community, over $30 \%$ of sewage sludge has been used as fertilizer in agriculture.

Agricultural land application appears to be a logical and reasonable way of treating sewage sludge, since it may improve many soil properties, such as $\mathrm{pH}$ and contents of organic matter and nutrients [4-6]. In Belgium, $57 \%$ of the sludge is applied to land. In France, $60 \%$ of the sewage sludge is used for land application [7]. Sewage sludge is effective as a fertilizer, increases dry matter yield of many crops [8], and can also improve soil physical properties such as porosity, aggregate stability, bulk density, and water retention and movement [9]. Although dewatered sewage sludge contains valuable nutrients such as nitrogen, phosphorus, organic matters, and essential trace elements, it also contains various toxins, especially heavy metals, which cause harm to the soil-plant system and further might pose a serious risk to human health $[10,11]$. The advantages and disadvantages caused by land application of sewage sludge have attracted the attention of environmental authorities, the public, and scientists [12].

According to statistics data of the Ministry of Construction of the People's Republic of China, the number of wastewater treatment plants was 427 in 2000 and increased rapidly to 708 in 2005 . Therefore, the volumes of sewage sludge increased correspondingly, and now up to $1.0 \times 10^{8} \mathrm{t}$ of sewage sludge is produced annually. There has been an increasing tendency in recent years to use sewage sludge as fertilizers in agriculture. The agricultural areas of land application of sewage sludge, usually in the suburbs of cities, involves nearly all the main food crops and vegetables in China such as rice, wheat, corn, millet, soybean, rye, taro, Chinese cabbage, cucumber, tomato, lettuce, hot pepper, cauliflower, and cabbage [13, 14].

Guangzhou, with a population of above 10 million, is one of the largest industrial centers and fastest expanding cities in China. Its overall economic power is the third among all China's cities and just after Shanghai and Beijing, contributing to $1 / 10$ of China's gross domestic product (excluding Hong Kong). It was expected that, by 2020, the volume of waste water in the center district of Guangzhou city will reach $4.30 \times 10^{6} \mathrm{~m}^{3} / \mathrm{d}$ [15], and the sludge produced will be $1.29 \sim 2.15 \times 10^{4} \mathrm{~m}^{3} / \mathrm{d}$ (98\% mois- ture), calculated by the method that the amount of sludge production is $0.3 \% \sim 0.5 \%$ of the volume of waste water. Therefore, how to dispose of and use this large amount of sludge safely and economically will be a common environmental problem to be concerned.

Recently, environmental awareness has been intensified, and the utilization and treatment of sewage sludge has become a major environmental concern throughout China. Therefore, it is necessary to monitor and evaluate the environmental quality of heavy metals before using the sludge in agricultural applications. A variety of evaluation methods for heavy metals were proposed from different perspectives, in which the mostly used methods are enrichment factor (EF) [16], the geoaccumulation index $\left(I_{\text {geo }}\right)$ [17], pollution load index [18], the potential ecological risk index $(R I)$ [19], excess after regression analysis [20], fuzzy subset theory [21], face graph [22], comprehensive pollution index [23], Nemerow comprehensive index $\left(P_{n}\right)$ [24], and secondary phase enrichment factor [25]. These methods represent the internationally advanced level in the evaluation of heavy metals in soil and sediment, but the potential ecological risk assessments on heavy metals in sludge during agricultural usage are much less studied. At the same time, the risk assessment of heavy metals would provide a certain theory support for risk management of sludge.

The main objectives of this study were to:

(1) Investigate the concentration and distribution of relatively hazardous elements ( $\mathrm{Mn}, \mathrm{Cr}, \mathrm{Pb}, \mathrm{Cu}, \mathrm{Ni}, \mathrm{Cd}$, and $\mathrm{Zn}$ )

(2) Assess the potential ecological risk of elements in sludge based on geo-accumulation index $\left(I_{\text {geo }}\right)$ and the potential ecological risk index $(R I)$

(3) Predicate the potential risk for agriculture, and provide evidence on the feasibility of sludge reuse for agronomic application.

\section{Materials and Methods}

\section{Sampling and Pre-Treatment}

Dewatered sludge samples were obtained from four WWTPs at Guangzhou (S1, S2, S3, and S4). The combined total volume of effluent in these four WWTPs accounts for 
Table 2. Physico-chemical properties of sludges from the selected municipal and industrial wastewater treatment plants.

\begin{tabular}{|c|c|c|c|c|c|c|c|c|c|c|}
\hline & $\begin{array}{c}\text { Moisture } \\
\text { content (\%) }\end{array}$ & $\mathrm{pH}$ & $\begin{array}{c}\text { Organic } \\
\text { carbon (\%) }\end{array}$ & $\begin{array}{c}\text { Total N } \\
(\%)\end{array}$ & $\begin{array}{c}\text { Total P } \\
(\%)\end{array}$ & $\begin{array}{c}\mathrm{Ca} \\
(\%)\end{array}$ & $\begin{array}{c}\mathrm{Mg} \\
(\%)\end{array}$ & $\begin{array}{c}\text { Na } \\
(\%)\end{array}$ & $\begin{array}{c}\mathrm{Fe} \\
(\%)\end{array}$ & $\begin{array}{c}\text { Total K } \\
(\%)\end{array}$ \\
\hline S1 & 83.2 & 7.85 & 32.2 & 3.11 & 2.04 & 3.71 & 0.15 & 5.32 & 1.53 & 1.08 \\
\hline S2 & 84.3 & 6.84 & 38.1 & 3.21 & 1.19 & 3.96 & 0.20 & 4.08 & 1.36 & 1.75 \\
\hline S3 & 80.0 & 6.35 & 35.2 & 3.72 & 3.62 & 2.82 & 0.17 & 6.42 & 1.44 & 1.77 \\
\hline S4 & 76.3 & 7.36 & 60.6 & 3.01 & 1.70 & 3.21 & 0.13 & 5.12 & 1.59 & 1.91 \\
\hline S5 & 76.2 & 7.45 & 62.1 & 1.25 & 1.87 & 12.95 & 0.33 & 5.13 & 0.26 & 0.67 \\
\hline S6 & 85.4 & 6.49 & 28.1 & 3.83 & 2.04 & 3.50 & 0.25 & 6.42 & 1.27 & 1.66 \\
\hline Mean & 80.9 & 7.06 & 42.72 & 3.02 & 2.08 & 5.03 & 0.21 & 5.42 & 1.24 & 1.47 \\
\hline
\end{tabular}

more than $60 \%$ of the total wastewater volume originating from Guangzhou. Details of WWTPs are presented in Table 1. In order to obtain more information about other types of sludge in Guangdong, the other two sludge types, including those from the papermaking mill in Guangzhou (S5) and the domestic WWTP (S6) from Zhaoqing adjacent to Guangzhou, were also collected separately. The locations of sample points are shown in Fig. 1. Samples were collected from the terminal conveyor belts of four WWTPs on the same day. Each sludge sample was collected four times during a sampling time that lasted for 2 hours and at intervals of $0.5 \mathrm{~h}$. The samples were air-dried at room temperature, ground, and homogenized in an agate mortar, sieved (mesh pore size: $0.14 \mathrm{~mm}$ ), and then stored in jars at room temperature.

\section{Physico-Chemical Analysis of the Sludge}

Significant agricultural parameters such as moisture content $(\%), \mathrm{pH}$ value, organic matter $(\mathrm{OM})$, total nitrogen
(TN), total phosphorus (TP), and the major elements such as calcium $(\mathrm{Ca})$, sodium $(\mathrm{Na})$, potassium $(\mathrm{K})$, magnesium $(\mathrm{Mg})$, and iron $(\mathrm{Fe})$ content of sludge from the WWPT were determined using standard analytical methods [26, 27]. Stated briefly, $\mathrm{pH}$ of sludge was measured in a preparation made up by a 1:5 ratio of sludge and water suspensions. The organic matter content of the sludge samples was determined by ashing at $500^{\circ} \mathrm{C}$ for 3 hours. The TN was measured by the Kjeldhal method. The contents of total $\mathrm{Na}, \mathrm{Ca}, \mathrm{Mg}, \mathrm{Fe}, \mathrm{P}$, and $\mathrm{K}$ were determined by atomic absorption spectrometry (AAS, Z-2000, Hitachi). All values obtained for these physicochemical properties are listed in Table 2.

\section{Determination of the Total Heavy Metal Concentration}

A subsample of $1.00 \mathrm{~g}$ of dry sludge $(<63 \mu \mathrm{m})$ was weighed directly in a dried, cleaned PTFE digestion vessel and $10 \mathrm{~mL}$ of $\mathrm{HF}(40 \% \mathrm{v} / \mathrm{v}), 15 \mathrm{~mL}$ of $\mathrm{HNO}_{3}(65 \% \mathrm{v} / \mathrm{v})$,

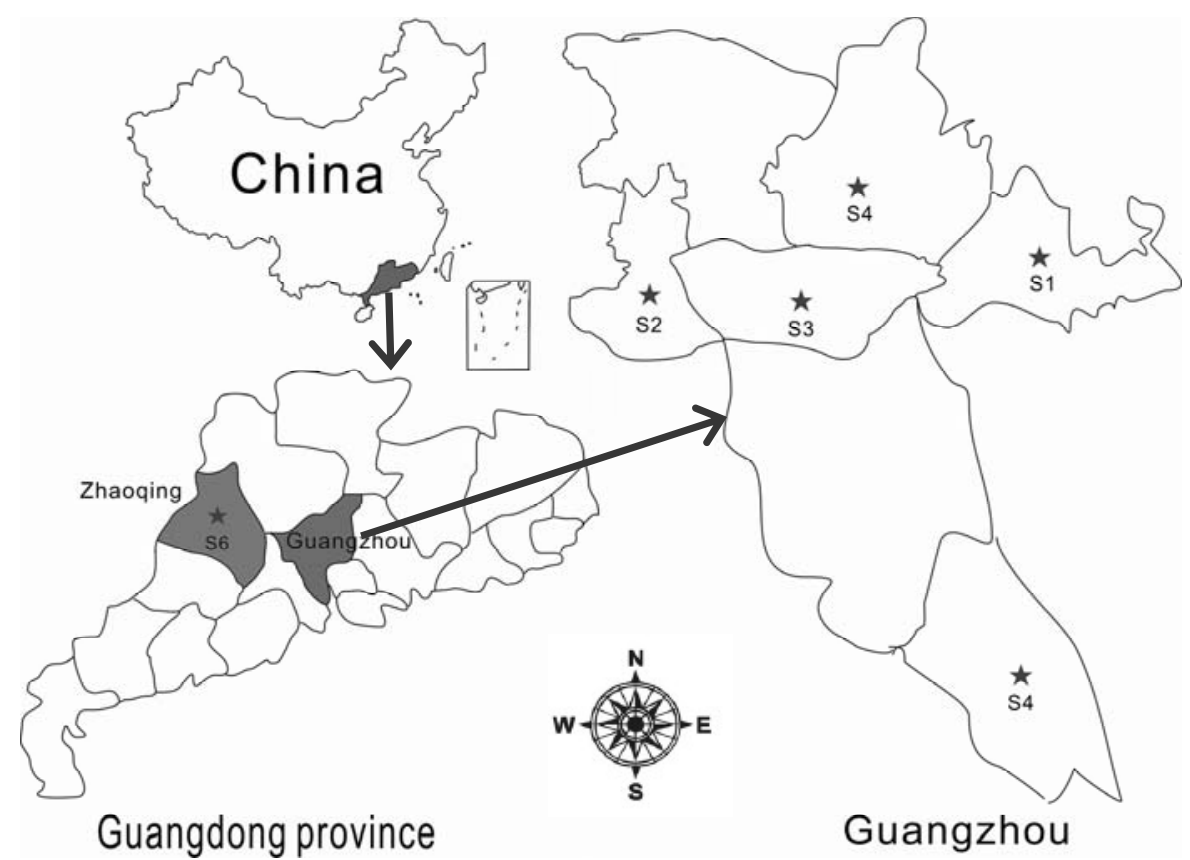

Fig. 1. Sketch map showing the sampling sites. 
Table 3. Pollution grades of geo-accumulation index of the metals.

\begin{tabular}{|c|c|l|}
\hline $\begin{array}{c}I_{\text {geo }} \\
\text { class }\end{array}$ & $I_{\text {geo }}$ value & \multicolumn{1}{|c|}{ Grades of quality } \\
\hline 0 & $I_{\text {geo }} \leq 0$ & Uncontaminated \\
\hline 1 & $0<I_{\text {geo }} \leq 1$ & Uncontaminated to moderately contaminated \\
\hline 2 & $1<I_{\text {geo }} \leq 2$ & Moderately contaminated \\
\hline 3 & $2<I_{g e o} \leq 3$ & Moderately to heavily contaminated \\
\hline 4 & $3<I_{\text {geo }} \leq 4$ & Heavily contaminated \\
\hline 5 & $4<I_{\text {geo }} \leq 5$ & Heavily to extremely contaminated \\
\hline 6 & $5<I_{g e o}$ & Extremely contaminated \\
\hline
\end{tabular}

and $1 \mathrm{~mL}$ of $\mathrm{HClO}_{4}(60 \% \mathrm{v} / \mathrm{v})$ were added. Afterward, the digestion vessel was placed in the chamber of the microwave system. The digestion conditions were optimized using different times and powers in the microwave system. The maximum recoveries were obtained at a power of $60 \%(400 \mathrm{~W})$ for $25 \mathrm{~min}$ [28]. After digestion, the sample solution was allowed to air-cool and then $4.00 \mathrm{~g}$ of boric acid were added. The solution was filtered through a Whatman No. 42 filter paper and quantitatively transferred to a $50 \mathrm{~mL}$ calibrated flask and diluted with deionized water.

\section{Potential Ecological Risk Assessment Methodology}

The geoaccumulation index $\left(I_{g e o}\right)$ has been used since the late 1960s, and has been widely employed in European trace metal studies. Originally used for bottom sediments [29], it has been successfully applied to the measurement of soil contamination [30]. The $I_{g e o}$ enables the assessment of contamination by comparing current and pre-industrial concentrations, although it is not always easy to reach preindustrial sediment layers. Pollution levels of toxic metals in sewage sludge for agricultural land use could be defined as the following equation:

$$
I_{\mathrm{geo}}=\log _{2} \frac{C_{n}}{1.5 B_{n}}
$$

...where: $C_{n}-$ the measured content of the metal $n$ in sewage sludge, $\mathrm{mg} / \mathrm{kg} ; B_{n}$ - the background or pristine value of the heavy metal, $\mathrm{mg} / \mathrm{kg}$. In this study, the back- ground value of individual metal is the mean value in soil of the Pearl River Delta in Table 5. The constant factor 1.5 is introduced to analyze natural fluctuations in the contents of a given substance in the environment and very small anthropogenic influences [31]. Müller [32] proposed seven classes of the geo-accumulation index, as shown in Table 3.

The assessment of ecological risks of toxic metals in sewage sludge was carried out using the potential ecological risk index $(R I)$ proposed by Hakanson [33]. $R I$ method covers a variety of researching domains, i.e. biological toxicology, environmental chemistry as well as ecology, and could evaluate ecological risks caused by toxic metals comprehensively. The calculating methods of $R I$ are listed below.

$$
\begin{gathered}
C_{f}^{i}=\frac{C_{n}^{i}}{C_{0}^{i}} \\
E_{r}^{i}=T_{r}^{i} \times C_{f}^{i} \\
R I=\sum_{i=1}^{n} E_{r}^{i}
\end{gathered}
$$

...where: $C_{f}^{i}$ is the single metal pollution index; $C_{n}^{i}$ is the concentration of heavy metal in samples, $\mathrm{mg} / \mathrm{kg} ; C_{0}^{i}$ is the reference value for the heavy metal, $\mathrm{mg} / \mathrm{kg}$. (In this study, the background value of individual metal is the mean in soil of the Pearl River Delta in Table 5); $E_{r}^{i}$ is the monomial potential ecological risk factor; $T_{r}^{i}$ is the metal toxic response factor, according to Hakanson [33], the values for each element are in the order of $\mathrm{Zn}=1<\mathrm{Cr}=2<\mathrm{Cu}=\mathrm{Ni}$ $=\mathrm{Pb}=5<\mathrm{As}=10<\mathrm{Cd}=30<\mathrm{Hg}=40 ; R I$-the potential ecological risk caused by overall contamination.

Hakanson [33] defined five categories of $E_{r}^{i}$ and four categories of $R I$, as shown in Table 4. $R I$ is the comprehensive potential ecological index, which is the sum of $E_{r}^{i}$. It represents the sensitivity of the biological community to the toxic substance and illustrates the potential ecological risk caused by the overall contamination [34, 35].

\section{Results and Discussion}

\section{Physicochemical Properties of Sludge from Select Wastewater Treatment Plants}

Table 2 presents the properties of sludge obtained from WWTPs in Guangzhou. The moisture content of the dewatered sludge was approximately $80 \%$, which is relatively

Table 4. Indices and grades of potential ecological risk of toxic metals contamination.

\begin{tabular}{|c|c|c|c|}
\hline$E_{r}^{i}$ value & $E_{r}^{i}$ Risk grades & $R I$ value & $R I /$ Risk grades \\
\hline$E_{r}^{i}<40$ & Low potential ecological risk & $R I<150$ & Low potential ecological risk \\
\hline $40 \leq E_{r}^{i}<80$ & Moderate potential ecological risk & $150 \leq R I<300$ & Moderate potential ecological risk \\
\hline $80 \leq E_{r}^{i}<160$ & Considerable potential ecological risk & $300 \leq R I<600$ & Considerable potential ecological risk \\
\hline $160 \leq E_{r}^{i}<320$ & High potential ecological risk & $R I \geq 600$ & Significantly high potential ecological risk \\
\hline$E_{r}^{i} \geq 320$ & Extremely high potential ecological risk & & \\
\hline
\end{tabular}


Table 5. Total contents of $\mathrm{Cu}, \mathrm{Pb}, \mathrm{Ni}, \mathrm{Mn}, \mathrm{Cr}, \mathrm{Zn}$, and $\mathrm{Cd}$ in sludge samples collected from select wastewater treatment plants, and the control standards for pollutants in sludges for agricultural use of China and other countries $(\mathrm{mg} / \mathrm{kg}$ dry matter).

\begin{tabular}{|c|c|c|c|c|c|c|c|}
\hline & $\mathrm{Cu}$ & $\mathrm{Pb}$ & $\mathrm{Ni}$ & $\mathrm{Mn}$ & $\mathrm{Cr}$ & $\mathrm{Zn}$ & $\mathrm{Cd}$ \\
\hline S1 & $4567 \pm 143$ & $81.2 \pm 2.8$ & $148 \pm 6$ & $1844 \pm 66$ & $121 \pm 4$ & $785 \pm 32$ & $5.99 \pm 0.18$ \\
\hline S2 & $274 \pm 6$ & $104 \pm 4$ & $132 \pm 6$ & $1152 \pm 34$ & $87 \pm 4$ & $987 \pm 34$ & $4.48 \pm 0.12$ \\
\hline S3 & $190 \pm 4$ & $82.4 \pm 2.7$ & $74 \pm 1$ & $214 \pm 10$ & $49.6 \pm 1.9$ & $909 \pm 28$ & $3.05 \pm 0.13$ \\
\hline S4 & $146 \pm 2$ & $69.9 \pm 1.2$ & $78 \pm 2$ & $394 \pm 9$ & $51.9 \pm 2.7$ & $609 \pm 22$ & $3.72 \pm 0.20$ \\
\hline S5 & $175 \pm 3$ & -a) & $103 \pm 3$ & $161 \pm 7$ & $19.4 \pm 0.6$ & $717 \pm 18$ & $2.14 \pm 0.10$ \\
\hline S6 & $93 \pm 1$ & $17.4 \pm 1.1$ & $51 \pm 1$ & $970 \pm 30$ & $15.5 \pm 0.4$ & $509 \pm 20$ & - \\
\hline Mean in China ${ }^{\text {b) }}$ & 533 & 115 & 79.1 & $397^{\mathrm{c})}$ & 222 & 1270 & 7.18 \\
\hline Mean in soil of the Pearl River Delta ${ }^{\mathrm{d})}$ & 33 & 40 & 21.2 & e)/ & 71.4 & 84.7 & 0.58 \\
\hline Murcia, Spain ${ }^{\mathrm{f}}$ & 204 & 58 & 17 & l & 38 & 487 & 1.10 \\
\hline Dom ažale, Slovenia ${ }^{\mathrm{g})}$ & 433 & 126 & 621 & l & 856 & 2032 & 2.78 \\
\hline \multicolumn{8}{|c|}{ Control standards for pollutants in sludges for agriculture use (Threshold values) } \\
\hline China $\mathrm{pH}<6.5^{\mathrm{h})}$ & 800 & 300 & 100 & 1 & 600 & 2000 & 5 \\
\hline China $\mathrm{pH} \geq 6.5^{\text {h) }}$ & 1500 & 1000 & 200 & 1 & 1000 & 3000 & 20 \\
\hline America $^{\mathrm{f}}$ & 1500 & 300 & 420 & / & 1200 & 2800 & 10 \\
\hline Canada $^{\mathrm{f}}$ & 500 & 200 & 100 & 1 & 1000 & 2000 & 10 \\
\hline $\mathrm{EU} \mathrm{pH}>7^{\mathrm{i})}$ & 1750 & 1200 & 400 & l & 1500 & 4000 & 40 \\
\hline $\mathrm{EU} \mathrm{pH}<7^{\mathrm{i})}$ & 1000 & 750 & 300 & I & 1000 & 2500 & 20 \\
\hline
\end{tabular}

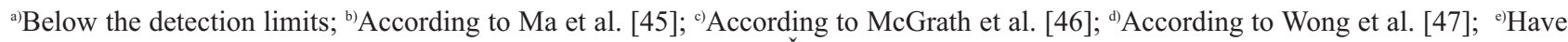
no statistical data; ${ }^{\mathrm{f}}$ According to Fuentes et al. [44]; ${ }^{\mathrm{g}}$ According to Ščančar et al. [43]; ${ }^{\mathrm{h}}$ From China's" Control Standards for Pollutants in Sludges for agriculture use (GB 18918-2002)" [48]; i From from the threshold values of heavy metals established in Directive $86 / 278 / \mathrm{EEC}$ as function of soil $\mathrm{pH}$

high, with $\mathrm{pH}$ ranging from 6.35 to 7.85 . The concentrations ranged from $281 \mathrm{~g} / \mathrm{kg}$ to $606 \mathrm{~g} / \mathrm{kg}$ for organic C, 12.5 $\mathrm{g} / \mathrm{kg}$ to $38.3 \mathrm{~g} / \mathrm{kg}$ for total $\mathrm{N}, 11.9 \mathrm{~g} / \mathrm{kg}$ to $36.2 \mathrm{~g} / \mathrm{kg}$ for total $\mathrm{P}$, and $6.7 \mathrm{~g} / \mathrm{kg}$ to $19.1 \mathrm{~g} / \mathrm{kg}$ for total $\mathrm{K}$. The aforementioned composition of dewatered sludge is similar to or higher than that reported for farmyard manure. In China, the mean composition of soil is: $10 \mathrm{~g} / \mathrm{kg}$ to $40 \mathrm{~g} / \mathrm{kg} \mathrm{OM}$, $1.0 \mathrm{~g} / \mathrm{kg}$ to $2.0 \mathrm{~g} / \mathrm{kg}$ total $\mathrm{N}, 0.44 \mathrm{~g} / \mathrm{kg}$ to $0.85 \mathrm{~g} / \mathrm{kg}$ total $\mathrm{P}$, and approximately $16 \mathrm{~g} / \mathrm{kg}$ total $\mathrm{K}$ [36]. All the parameters closely reflect those found in the bibliography for sludge of similar characteristics, some of which has been used for soil improvement [37-41]. Comparing the contents of sludge with those of soil, the former has higher organic $\mathrm{C}$, total $\mathrm{N}$, and total $\mathrm{P}$, but lower total $\mathrm{K}$, suggesting high potential agricultural benefits for practical application.

\section{Total Concentrations of Heavy Metals in Sewage Sludge}

Total $\mathrm{Cu}, \mathrm{Pb}, \mathrm{Zn}, \mathrm{Cr}, \mathrm{Mn}, \mathrm{Cd}$, and Ni contents, as well as the control standards for pollutants in sludge for agricultural use in China and other countries for municipal WWTP, are listed in Table 5. Generally, the sludge samples shown in Table 5 had higher concentrations of $\mathrm{Cu}$ and $\mathrm{Zn}$ but relatively lower concentrations of $\mathrm{Cr}, \mathrm{Ni}$, and $\mathrm{Pb}$.
Similar results on the differences in the concentrations of heavy metals have been reported by Alvarez et al. [42] and Ščančar et al. [43]. In addition, the amounts of $\mathrm{Cu}$ in $\mathrm{S} 1$, and $\mathrm{S} 2, \mathrm{~Pb}$, and $\mathrm{Cr}$ in six sludge sites except $\mathrm{S} 5$ and $\mathrm{S} 6, \mathrm{Cd}$ in six sludge sites except $\mathrm{S} 6$, and $\mathrm{Ni}$ and $\mathrm{Zn}$ in all the sludge sites were higher than that in Murcia, Spain [44]. However, the amount of $\mathrm{Pb}, \mathrm{Ni}, \mathrm{Cr}$, and $\mathrm{Zn}$ in six sludge sites, $\mathrm{Cd}$ in $\mathrm{S} 4$ to $\mathrm{S} 6$, and $\mathrm{Cu}$ in all sludge sites except $\mathrm{S} 1$ were lower than that reported by Domažale, Slovenia [43]. The concentrations of heavy metals in sludge from $\mathrm{S} 1$ and $\mathrm{S} 2$ were significantly higher $(\mathrm{P}<0.05)$ than that in other sampling sites because industrial wastewater constituted a large proportion of effluent in these two plants. Compared with the sludge in the study by Domžale (Slovenia) [43], the concentrations of $\mathrm{Cu}, \mathrm{Pb}, \mathrm{Ni}, \mathrm{Cr}$, and $\mathrm{Zn}$ in $\mathrm{S} 1$ were approximately 22, 1.4, 8.7, 3.2, and 1.6 times, respectively. The higher concentrations may possibly be attributed to the fact that $\mathrm{S} 1$ is situated in a large industrial area in Guangzhou, where several chemical plants and electrical factories are located. The higher concentrations of heavy metals in sludge from S1 suggested that effluent from certain factories do not meet specified discharge standards. As a consequence, these pollutants settled and accumulated in the sludge and contributed to high heavy metal concentrations in the sewage sludge. 
Table 6. Geoaccumulation index of heavy metals in sludge samples and their grading of potential pollution levels.

\begin{tabular}{|c|c|c|c|c|c|c|c|c|c|c|c|c|c|c|}
\hline \multirow{2}{*}{ No. } & \multicolumn{2}{|c|}{$\mathrm{Cu}$} & \multicolumn{2}{|c|}{$\mathrm{Pb}$} & \multicolumn{2}{|c|}{$\mathrm{Ni}$} & \multicolumn{2}{|c|}{$\mathrm{Mn}$} & \multicolumn{2}{|c|}{$\mathrm{Cr}$} & \multicolumn{2}{|c|}{$\mathrm{Zn}$} & \multicolumn{2}{|c|}{$\mathrm{Cd}$} \\
\hline & $I_{g e o}$ & $R^{*}$ & $I_{g e o}$ & $R$ & $I_{g e o}$ & $R$ & $I_{g e o}$ & $R$ & $I_{g e o}$ & $R$ & $I_{g e o}$ & $R$ & $I_{g e o}$ & $R$ \\
\hline $\mathrm{S} 1$ & 6.53 & 6 & 0.44 & 1 & 2.22 & 3 & 3.21 & 4 & 0.18 & 1 & 2.63 & 3 & 2.78 & 3 \\
\hline $\mathrm{S} 2$ & 2.47 & 3 & 0.79 & 1 & 2.05 & 3 & 2.54 & 3 & -0.30 & 0 & 2.96 & 3 & 2.36 & 3 \\
\hline S3 & 1.94 & 2 & 0.46 & 1 & 1.22 & 2 & 0.11 & 1 & -1.11 & 0 & 2.84 & 3 & 1.81 & 2 \\
\hline S4 & 1.56 & 2 & 0.22 & 1 & 1.29 & 2 & 0.99 & 1 & -1.05 & 0 & 2.26 & 3 & 2.10 & 3 \\
\hline S5 & 1.82 & 2 & - & - & 1.70 & 2 & -0.30 & 0 & -2.46 & 0 & 2.50 & 3 & 1.30 & 2 \\
\hline S6 & 0.91 & 1 & -1.79 & 0 & 0.68 & 1 & 2.29 & 3 & -2.79 & 0 & 2.00 & 2 & - & - \\
\hline
\end{tabular}

$* R-$ rank of $I_{\text {geo }}$ classification

The amount of $\mathrm{Zn}$ was comparatively higher than that of other heavy metals. This finding may be attributed to the fact that almost all urban drainage pipes in China are made of galvanized material. $\mathrm{Mn}$ and $\mathrm{Cu}$ content were the second highest, whereas $\mathrm{Pb}$ and $\mathrm{Cr}$ content were relatively lower. These results concur with the findings of Ma et al. [45]. Comparing the composition of Guangzhou sludge with the mean in China, the former exhibited lower concentrations for all heavy metals except for $\mathrm{Cu}$ in $\mathrm{S} 1$ and $\mathrm{Ni}$ in $\mathrm{S} 1, \mathrm{~S} 2$, and S5. Compared with sludge from other cities (Domžale and Murcia) [43], the concentrations of $\mathrm{Cu}, \mathrm{Zn}$, and $\mathrm{Pb}$ in S3, S4, S5, and S6 were relatively low. Based on Chinese mean levels, the concentrations of heavy metals in the aforementioned sites were similarly low. Statistical analysis showed no significant difference in the total concentrations of heavy metals in sludge between municipal and industrial WWTPs. If the discharge standards for industrial wastewater in China were enforced strictly, the metal concentrations in sludge could be reduced effectively. Wastewater sources for municipal WWTPs include industrial effluents, domestic wastewater, and surface runoff. Heavy metal control in the wastewater sources of municipal WWTPs is significantly harder than that of industrial WWTPs.

The maximum heavy metal content in sewage sludge permitted by China's control standards for pollutants in sludge for agricultural use (GB 18918-2002) [48] is listed in Table 5. A comparison of metal concentrations in sludge with the permissible values indicated that the concentrations of $\mathrm{Cu}$ and $\mathrm{Cd}$ in $\mathrm{S} 1, \mathrm{Ni}$ in $\mathrm{S} 1, \mathrm{~S} 2$, and $\mathrm{S} 5$ exceeded the permissible values, consequently restricting the use of sludge in agriculture. Sludge, especially from S1 and S2, is evidently unsuitable for agricultural use because of high $\mathrm{Cu}$ content in S1 and Ni content in S1 and S2. On the other hand, metal concentrations in the S3, S4, and S6 samples were less than the permissible values. Therefore, the sludge from these sites could be safely used in agriculture. At sites $\mathrm{S} 1$ and $\mathrm{S} 2$, the total $\mathrm{Cu}, \mathrm{Zn}, \mathrm{Pb}, \mathrm{Cr}, \mathrm{Cd}$ and $\mathrm{Ni}$ contents in sludge were found to exceed the discharge standards of pollutants for municipal WWTP (GB18918-2002) [48]. Moreover, except $\mathrm{Pb}$ concentrations in $\mathrm{S} 5$ and $\mathrm{S} 6$, and $\mathrm{Cr}$ in S3, S4, S5, and S6, the concentrations of other metals listed in Table 5 were higher than those reported in the crop soil background data for Guangzhou. Therefore, sludge from S3, S4, and S6 can be used as good organic fertilizers, whereas those from S1 and S2 should not be used directly unless subjected to bioremediation [49] and chemical remediation [50]. Soil contamination, especially with heavy metals, is a serious problem in China. For example, concentrations of heavy metals in 36,000 ha sampled from 300,000 ha of basic agricultural protected cropland [51] in 2000 were found to exceed the permissible values specified in state standards for croplands. A strict enforcement of state-stipulated standards should be established to limit the indiscriminate use of sludge in croplands.

\section{Potential Risk Assessment of Heavy Metals in Municipal Sludge}

\section{Contamination Degree Based on $I_{\text {geo }}$}

To make sure that the application of $I_{\text {geo }}$ can obtain the environmental information of heavy metal pollution in the sludge for agricultural purposes, it was assumed that the range of agricultural utilization of the sludge was the Pearl River Delta region, which was in conformity with the requirements for selection of geochemical background values of heavy metals [52]. The $I_{\text {geo }}$ of heavy metals in sludge and classification of the degree of pollution were obtained by Formula (1) and shown in Table 6.

According to the $I_{\text {geo }}$ values listed in Table 6, it can be seen that the content of $\mathrm{Cu}$ and $\mathrm{Mn}$ in S1 sludge were far more than the average background value of crop soil of the Peal River Delta and the pollution levels were the extreme strong pollution and strong pollution, respectively. $\mathrm{Zn}$ and $\mathrm{Ni}$ reached the level of moderate pollution, but $\mathrm{Pb}$ and $\mathrm{Cr}$ were uncontaminated. The results of $I_{g e o}$ show that the risks of heavy metals in S1 sludge are in the decreasing order of $\mathrm{Cu}>\mathrm{Mn}>\mathrm{Cd}>\mathrm{Zn}>\mathrm{Ni}>\mathrm{Pb}>\mathrm{Cr}$. In $\mathrm{S} 2$ sludge, $\mathrm{Zn}$ and $\mathrm{Mn}$ were the main pollution elements, reaching to the level of moderate pollution and the level between moderate and strong pollution, respectively. Moreover, $\mathrm{Cu}$ and $\mathrm{Ni}$ reached the level of moderate pollution, but $\mathrm{Pb}$ and $\mathrm{Cr}$ was almost null pollution. In S2 sample, it could be concluded that the contamination degree of heavy metals was ranked in the order of $\mathrm{Zn}>\mathrm{Mn}>\mathrm{Cu}>\mathrm{Cd}>\mathrm{Ni}>\mathrm{Pb}>\mathrm{Cr}$. Comparing $\mathrm{S} 1$ sludge with $\mathrm{S} 2$ sludge, it was found that the reason for the high degree 
Table 7. Potential ecological risk assessment results of toxic metals in sludges.

\begin{tabular}{|c|c|c|c|c|c|c|c|c|c|}
\hline \multirow{2}{*}{ No. } & \multicolumn{7}{|c|}{$E_{r}^{i}$} & \multirow{2}{*}{$R I$} & \multirow{2}{*}{ Grades* } \\
\hline & $\mathrm{Cu}$ & $\mathrm{Pb}$ & $\mathrm{Ni}$ & $\mathrm{Mn}$ & $\mathrm{Cr}$ & $\mathrm{Zn}$ & $\mathrm{Cd}$ & & \\
\hline $\mathrm{S} 1$ & 691.97 & 10.15 & 34.91 & 13.92 & 3.39 & 9.27 & 309.83 & 1073 & Very high risk \\
\hline $\mathrm{S} 2$ & 41.52 & 13.00 & 31.13 & 8.69 & 2.44 & 11.65 & 231.72 & 340 & Considerable risk \\
\hline $\mathrm{S} 3$ & 28.79 & 10.30 & 17.45 & 1.62 & 1.39 & 10.73 & 157.76 & 228 & Moderate risk \\
\hline $\mathrm{S} 4$ & 22.12 & 8.74 & 18.40 & 2.97 & 1.45 & 7.19 & 192.41 & 253 & Moderate risk \\
\hline S5 & 26.52 & / & 24.29 & 1.22 & 0.54 & 8.47 & 110.69 & 171 & Moderate risk \\
\hline S6 & 14.09 & 2.18 & 12.03 & 7.32 & 0.43 & 6.01 & l & 42 & Low risk \\
\hline
\end{tabular}

*Grades - grades of potential ecological risk of the environment

of pollution in the former was that it is located in the industrial development zone and thus the proportion of industrial sewage entering water was higher than the latter. Due to the robust development of the electronics industry, part of $\mathrm{Mn}$ and $\mathrm{Ni}$ industrial sewage increased greatly and accumulated in sludge. Combined with the results of $I_{\text {geo }}$ assessment, it can be concluded that there are serious risks in agricultural utilization for the existing $\mathrm{Cu}$ and $\mathrm{Zn}$ in these six kinds of sludge samples, which needs more strict control on the emission of $\mathrm{Cu}, \mathrm{Mn}, \mathrm{Ni}$ and other metals in industrial wastewater.

\section{Potential Ecological Risk Assessment Based on RI}

Hakanson [33] suggested that the potential ecological risk index is mainly related to the concentration, type, quantity, toxicity, and sensitivity of metal pollutants, etc. The relationship between the degree of pollution and the risk coefficient $\left(E_{r}^{i}\right)$, as well as the potential ecological risk index $(R I)$, was summarized in Table 4. According to Hakanson's methodology, a metal toxic coefficient should include information on both sides: metals harmful to the human body and aquatic ecosystems. Therefore, the "principle of abundance" and "release effect" should be discussed. At the same time, the heavy metals in sludge harm the environment through the two principles: "principle of abundance" and "release effect" during agricultural use, which meets several necessary prerequisites in the ecological evaluation system based on the abundance of elements and the principle of release. The toxic coefficients $\left(T_{r}^{i}\right)$ selected in this paper were: $T_{r}^{i}(\mathrm{Mn})=T_{r}^{i}(\mathrm{Zn})=1, T_{r}^{i}(\mathrm{Cr})=2$, $T_{r}^{i}(\mathrm{~Pb})=T_{r}^{i}(\mathrm{Ni})=T_{r}^{i}(\mathrm{Cu})=5, T_{r}^{i}(\mathrm{Cd})=30$, respectively [33]. The results of pollution evaluation of heavy metals in sewage sludge can be seen in Table 7 .

The potential ecological risk assessment results of toxic metals in six sludges were summarized in Table 7. For the monomial potential ecological risk, $E_{r}^{i}$ values for $\mathrm{Cu}$ in $\mathrm{S} 1$ sludge was above 320, which indicated that $\mathrm{Cu}$ denoted extremely high risk to the environment. $E_{r}^{i}$ values for $\mathrm{Pb}$, $\mathrm{Cr}, \mathrm{Ni}, \mathrm{Mn}$, and $\mathrm{Zn}$ in six sludges were below 40 , indicating low risk. On the whole, the risk indices $\left(E_{r}^{i}\right)$ in $\mathrm{S} 1$ were ranked in the following order: $\mathrm{Cu}>\mathrm{Cd}>\mathrm{Ni}>\mathrm{Mn}>\mathrm{Pb}>\mathrm{Zn}>\mathrm{Cr}$, while the metals in the S2 sludge varied in the order of
$\mathrm{Cd}>\mathrm{Cu}>\mathrm{Ni}>\mathrm{Pb}>\mathrm{Zn}>\mathrm{Mn}>\mathrm{Cr}$. Except $\mathrm{S} 6$, all the $E_{r}^{i}$ values for $\mathrm{Cd}$ in other five sludges were more than 110, indicating that $\mathrm{Cd}$ posed more risks to the local ecosystem than the other heavy metals except $\mathrm{Cu}$ in $\mathrm{S} 1$. The very high risk to environments posed by $\mathrm{Cd}$ should give rise to widespread concerns. Consequently, it can be concluded that the main ecological risk element in $\mathrm{S} 1$ is $\mathrm{Cu}$ and $\mathrm{Cd}$, and in $\mathrm{S} 2, \mathrm{~S} 3$, $\mathrm{S} 4$, and $\mathrm{S} 5$ is $\mathrm{Cd}$, which should be conducted during the pretreatment before the sludge was used in agriculture, such as the bioleaching technology with low costs, good leaching effects, and simple operations [53].

In order to quantify the overall potential ecological risk of observed metals in sludge, $R I$ was calculated as the sum of all seven risk factors. Descriptive statistics of $R I$ were shown in Table 7. $R I$ in the six sludge samples ranged from 42 to 1,073 , with an average of 351 . It is clear that the grade of potential ecological risk of S1 is very high, and S2 was considerable ecological risk, S3, S3, and S4 sludge have moderate ecological risk, while S6 has low risk. It could be concluded that the potential ecological risks $(R I)$ of heavy metals in six sludge samples were ranked in the order of $\mathrm{S} 1>\mathrm{S} 2>\mathrm{S} 4>\mathrm{S} 3>\mathrm{S} 5>\mathrm{S} 6$.

$R I$ could characterize the sensitivity of the local ecosystem to the toxic metals and represent ecological risk resulting from overall contamination. From Table 5, it was shown that element of $\mathrm{Cd}$ accounted for most of the total risks, and the percentages arranged from $28.8 \%$ to $76.05 \%$ with a mean of $61.4 \%$. $\mathrm{Cu}$ ranked second among the metals contributing to the total risk, and the average was $24.52 \%$, which was followed by $11.7 \%(\mathrm{Ni}), 5.18 \%(\mathrm{Zn}), 3.98 \%$ $(\mathrm{Mn}), 3.59 \%(\mathrm{~Pb})$, and $0.59 \%(\mathrm{Cr})$. The most toxic metals, i.e. $\mathrm{Cd}$, contributed more than $60 \%$ of the total potential ecological risk in S2, S3, S4, and S5. It could be concluded that the high ecological risk was primarily dominated by metals of $\mathrm{Cd}$ in $\mathrm{S} 2, \mathrm{~S} 3, \mathrm{~S} 4$, and $\mathrm{S} 5$, and $\mathrm{Cu}$ in $\mathrm{S} 1$. In the whole, $\mathrm{Cu}$ and $\mathrm{Cd}$ were the dominant risk elements in the $\mathrm{S} 1$, and $\mathrm{Cd}$ was the dominant risk element in the $\mathrm{S} 2, \mathrm{~S} 3, \mathrm{~S} 4$, and S5.

The evaluation targets in soil and river sediments are $\mathrm{Cu}, \mathrm{Pb}, \mathrm{Zn}, \mathrm{Cr}, \mathrm{Ni}, \mathrm{Mn}$, which were the same as those in control projects of heavy metals in sludge during agricultural applications. In order to explain the applicability of $I_{\text {geo }}$ and $R I$ in ecological risk evaluation of heavy metals in 
Table 8 . The range and the corresponding pollution degree of $C_{f}^{i}$ and $P_{n}$.

\begin{tabular}{|c|c|c|c|}
\hline Range of $C_{f}^{i}$ & $C_{f}^{i} /$ Degree of pollution & Range of $P_{n}$ & $P_{n}$ /Domain of pollution \\
\hline$C_{f}^{i}<1$ & Low contamination factor & $P_{n} \leq 0.7$ & Safety domain \\
\hline $1 \leq C_{f}^{i}<3$ & Moderate contamination factor & $0.7<P_{n} \leq 1.0$ & Precaution domain \\
\hline $3 \leq C_{f}^{i}<6$ & Considerable contamination factor & $1.0<P_{n} \leq 2.0$ & Slightly polluted domain \\
\hline$C_{f}^{i} \geq 6$ & Very high contamination factor & $2.0<P_{n} \leq 3.0$ & Moderately polluted domain \\
\hline & & $P_{n}>3.0$ & Seriously polluted domain \\
\hline
\end{tabular}

Table 9. $C_{f}^{i}$ and $P_{n}$ assessment results of toxic metals in sludges.

\begin{tabular}{|c|c|c|c|c|c|c|c|c|}
\hline \multirow{2}{*}{ No. } & \multicolumn{7}{|c|}{$C_{f}^{i}$} & \multirow{2}{*}{$P_{n}$} \\
\hline & $\mathrm{Cu}$ & $\mathrm{Pb}$ & $\mathrm{Ni}$ & $\mathrm{Mn}$ & $\mathrm{Cr}$ & $\mathrm{Zn}$ & $\mathrm{Cd}$ & \\
\hline $\mathrm{S} 1$ & 138.39 & 2.03 & 6.98 & 13.92 & 1.69 & 9.27 & 10.33 & 99.58 \\
\hline $\mathrm{S} 2$ & 8.30 & 2.60 & 6.23 & 8.69 & 1.22 & 11.65 & 7.72 & 7.73 \\
\hline S3 & 5.76 & 2.06 & 3.49 & 1.62 & 0.69 & 10.73 & 5.26 & 8.16 \\
\hline S4 & 4.42 & 1.75 & 3.68 & 2.97 & 0.73 & 7.19 & 6.41 & 5.78 \\
\hline S5 & 5.30 & I & 4.86 & 1.22 & 0.27 & 8.47 & 3.69 & 6.45 \\
\hline S6 & 2.82 & 0.44 & 2.41 & 7.32 & 0.22 & 6.01 & I & 5.53 \\
\hline
\end{tabular}

sludge, the contamination factor $\left(C_{f}^{i}\right)$ [54] and Nemerow's synthetical pollution index $\left(P_{n}\right)$ [24] are also applied to evaluate the pollution of heavy metals in sludge.

The $C_{f}^{i}$ of each heavy metal was defined as the ratio of its concentration to the background value of the corresponding metal using the following equation:

$$
C_{f}^{i}=\frac{C_{n}^{i}}{C_{0}^{i}}
$$

...where, $C_{n}^{i}$ is the mean content of metals from sludge, and $C_{0}^{i}$ is the pre-industrial concentration of individual metal.

Nemerow's synthetic pollution index was applied to assess soil environmental quality in a previous study [24]. In the present study, this method was utilized for the degree of soil environmental pollution and integrative assessment of soil environmental quality for the sludge application in agricultural land use. The pollution index $\left(P_{n}\right)$ was defined as the following equation:

$$
\begin{gathered}
P_{n}=\sqrt{\frac{\left(\operatorname{Max} P_{i}^{2}+\bar{P}_{i}\right)^{2}}{2}} \\
P_{i}=\frac{C_{i}}{S_{i}}
\end{gathered}
$$

...where $P_{n}$ is Nemerow's synthetic pollution index, $P_{i}$ is the pollution index of the ith heavy metal, $C_{i}$ is the measured concentration of the ith heavy metal, $S_{i}$ is the required stan- dard of the ith heavy metal, and $P_{i}$ and $\operatorname{Max} P_{i}$ are the average and the maximum value of the pollution indices of all heavy metals respectively.

In this study, the background value of individual metal in sediments from the Pearl River Delta is applied as the pre-industrial concentration of $C_{0}^{i}$ and $S_{\mathrm{i}}$. The background value of individual metal is the mean in soil of the Pearl River Delta in Table 5. The classification criteria of $C_{f}^{i}$ and $P_{n}$ are presented in Table 8. The $C_{f}^{i}$ and $P_{n}$ assessment results are shown in Table 9.

From the results of $C_{f}^{i}$ evaluation, $\mathrm{Zn}$ was considerable contamination. However, ecological risk caused by $\mathrm{Zn}$ was low. The $P_{n}$ values of six sludges were more than 3 and the domain of pollution for all the sludges were seriously polluted domain, which were not consistent to the $R I$ evaluation. From the results of geo-accumulation evaluation, $\mathrm{Cd}$ was mainly in the moderate to heavily contaminated degree. However, ecological risk caused by $\mathrm{Cd}$ was considerable or high due to its high toxicity. On the other hand, $\mathrm{Pb}$, $\mathrm{Zn}$, and $\mathrm{Mn}$ accumulated significantly in the sludge, but their ecological risks were relatively low. Thus it can be seen that the $I_{g e o}, C_{f}^{i}$, and $P_{n}$ methods were mainly focused on the accumulation levels of individual metal without regard to the toxic response factor. Potential ecological risk index $(R I)$ could describe both ecological risk caused by single pollutant and overall risk or contamination from varied pollutants. When the environmental quality was evaluated, four assessment methods should be comprehensively considered in order to get the more comprehensive and accurate assessment results. 


\section{Conclusions}

Municipal sludge had high organic carbon, and was rich in such nutrients as $\mathrm{N}$ and $\mathrm{P}$, showing potential for use in nutrient modification. The total concentrations of $\mathrm{Cu}$ in $\mathrm{S} 1$, $\mathrm{Ni}$ in S1, S2 and S5, and Cd in S5 exceeded the allowable values for agriculture land use. Only the heavy metals in samples S3 and S4 were below the permissible values in the national application standard of acid soil in China (GB18918-2002). This result showed promise with respect to agricultural applications for S3, S4, and S6. However, the total contents of heavy metals in S1, S2, and S5 were high, and treatment by remediation is necessary before application in agriculture.

Combined with the results of $I_{g e o}$ assessment, it can be concluded that there are serious risks in agricultural utilization for the existing $\mathrm{Cu}$ and $\mathrm{Zn}$ in these six kinds of sludge, which need more strict control on the emissions of $\mathrm{Cu}, \mathrm{Mn}$, $\mathrm{Ni}$ and other metals in industrial wastewater. Except for S6, all the $E_{r}^{i}$ values for $\mathrm{Cd}$ in the other five sludge samples were more than 110 , indicating that $\mathrm{Cd}$ posed more risks to the local ecosystem than the other heavy metals except $\mathrm{Cu}$ in $\mathrm{S} 1$. The potential ecological risks $(R I)$ of heavy metals in six sludges were ranked in the order $\mathrm{S} 1>\mathrm{S} 2>\mathrm{S} 4>$ $\mathrm{S} 3>\mathrm{S} 5>\mathrm{S} 6$.

Comparing the risk values of the heavy metals based on different methods, the main reason for the disagreements may be that the assessment methods of $I_{g e e}, C_{f}^{i}$, and $P_{n}$ ignore the toxic response factors of the different heavy metals. $R I$ considers both the total concentration and toxic response factors of the heavy metals. The different assessment methods should be thoroughly considered for the sludges used for agricultural purposes to obtain more comprehensive and accurate assessment results.

\section{Acknowledgements}

The authors gratefully acknowledge the support provided by the National Natural Science Foundation of China (No. 51308132), the Natural Science Foundation of Guangdong Province (S2013040013022), the Scientific and Technological Planning Project of Guangdong Province (No. 2012B050300023), the foundation for distinguished young talents in higher education of Guangdong, China (No. LYM11059).

\section{References}

1. DONG B., LIU X.G., DAI L.L., DAI X.H. Changes of heavy metal speciation during high-solid anaerobic digestion of sewage sludge. Bioresource Technol. 131, 152, 2013.

2. HALL J.E. Sewage sludge production, treatment and disposal in the European Union. J. Chart. Inst. Water E. 9, 335, 1995.

3. ANTONIO R.R., MARÍA R.M.L., NURIA F.D. Pasture and soil zinc evolution in forest and agriculture soils of Northwest Spain three years after fertilisation with sewage sludge. Agri. Ecosyst. Environ. 150, 111, 2012.
4. UYSAL A., DILSAD Y.Y., DEMIRER G.N. The determination of fertilizer quality of the formed struvite from effluent of a sewage sludge anaerobic digester. J. Hazard. Mater. 181, 248, 2010.

5. FERREIRO-DOMÍNGUEZ N., RIGUEIRO-RODRÍGUEZ A., MOSQUERA-LOSADA M.R. Sewage sludge fertiliser use: Implications for soil and plant copper evolution in forest and agronomic soils. Sci. Total Environ. 424, 39, 2012.

6. ROIG N., SIERRA J., MARTÍ E., NADAL M., SCHUHMACHER M., DOMINGO J.L. Long-term amendment of Spanish soils with sewage sludge: Effects on soil functioning. Agri. Ecosyst. Environ. 158, 41, 2012.

7. MAISONNAVE V., MONTREJAUD-VIGNOLES M., BONNIN C., REVEL J.C. Impact on crops, plants and soils of metal trace elements transfer and flux, after spreading of fertilizers and biosolids. Water Sci. Technol. 46, 217, 2002.

8. TSADILAS C.D., MATSI T. Influence of sewage sludge application on soil properties and on distribution and availability of heavy metal fraction. Commun. Soil Sci. Plant 26, 2603, 1995.

9. KARAPANAGIOTIS N., STERRITT R., LESTER J. N. Heavy metals complexation in sludge amended soil: the role of organic matter in metal retention. Environ. Technol. 12, 1107, 1991.

10. MÉNDEZ A., GÓMEZ A., PAZ-FERREIRO J., GASCÓ G. Effects of sewage sludge biochar on plant metal availability after application to a Mediterranean soil. Chemosphere 89, 1354, 2012.

11. WANG Q.R., CUI Y.S., LIU X.M., DONG Y.T., CHRISTE P. Soil contamination and plant uptake of heavy metals at polluted sites in China. J. Environ. Sci. Health A Toxic/Hazard. Subst. Environ. Eng. 38, 823, 2003.

12. SMITH S.R. A critical review of the bioavailability and impacts of heavy metals in municipal solid waste composts compared to sewage sludge. Environ. Int. 35, 142, 2009.

13. WANG M.J. Land application of sewage sludge in China. Sci. Total Environ. 197, 149, 1997.

14. CAO H., IKEDA S. Exposure assessment of heavy metals resulting from farmland application of wastewater sludge in Tianjin, China: the examination of two existing national standards for soil and farmland used sludge. Risk. Anal. 20, 613, 2000.

15. CHEN Y.L., WANG C.X., NIU Y., PEN P. A. Study on treatment and disposal of sludge of guangzhou WWTP. Chinese. Munic. Eng. (1), 38, 2007 [In Chinese].

16. CAEIRO S., COSTA M.H., RAMOS T.B., FERNANDES F., SILVEIRA N., COIMBRAA., MEDEIROS G., PAINHO M. Assessing heavy metal contamination in Sado Estuary sediment: An index analysis approach. Ecol. Indic. 5, 151, 2005.

17. FATMA Ç., MÜNIR G.Z.L., OSMAN B.D., ÖZLEM F. An assessment of metal pollution in surface sediments of Seyhan dam by using enrichment factor, geoaccumulation index and statistical analyses. Environ. Monit. Assess. 152, 309, 2009.

18. AMIN B., ISMAIL A., ARSHAD A., YAP C.K., KAMARUDIN M.S. Anthropogenic impacts on heavy metal concentrations in the coastal sediments of Dumai, Indonesia. Environ. Monit. Assess. 148, 291, 2009.

19. CAO H.C., LUAN Z.Q., WANG J.D., ZHANG X.L. Potential ecological risk of cadmium, lead and arsenic in agricultural black soil in Jilin province, China. Stoch. Environ. Res. Risk. A, 23, 57, 2009.

20. HILTON J., DAVISON W., OCHSENBEIN U. A mathematical model for analysis of sediment core data: implications for enrichment factor calculation and trace metal transport mechanisms. Chem. Geol. 48, 281, 1985. 
21. LI T., CAI S.M., YANG H.D., WANG X.L., WU S.J., REN X.Y. Fuzzy comprehensive-quantifying assessment in analysis of water quality: a case study in lake Honghu, China. Environ. Eng. Sci. 26, 451, 2009.

22. FERRARI J.R., LOOKINGBILL T.R., NEEL M.C. Two measures of landscape-graph connectivity: assessment across gradients in area and configuration. Landscape Ecol. 22, 1315, 2007.

23. LI W.X., ZHANG X.X., WU B., SUN S.L., CHEN Y.S., PAN W.Y., ZHAO D.Y., CHENG S.P. A comparative analysis of environmental quality assessment methods for heavy metal-contaminated soils. Pedosphere, 18, 344, 2008.

24. CHEN J. L., SHI Z., ZHU Y. W. Assessment and mapping of environmental quality in agricultural soils of Zhejiang Province, China. J. Environ. Sci. China. 19, 50, 2007.

25. BHATTACHARYA A., ROUTH J., JACKS G., BHATTACHARYA P., MÖRTH M. Environmental assessment of abandoned mine tailings in Adak, Västerbotten district (northern Sweden). Appl. Geochem. 21, 1760, 2006.

26. EPA (Environmental Protection Administration, PR China) . Ministry of Rural and Urban Construction PR China, Determination method for municipal sludge in wastewater treatment plant(CJ/T221-2005).Standard Press of China, Beijing, pp. 1-30, 2005 [In Chinese].

27. LIU G.S. Soil Physical and Chemical Analysis and Description of Soil Profiles. Standard Press of China, Beijing, pp. 1-253, 1996 [In Chinese].

28. ALVAREZ A.E., MOCHÓN C.M., SÁNCHEZ J.C.J., RODRÍGUEZ M.T. Determination of heavy metals in sewage sludge by microwave acid digestion and inductively coupled plasma atomic emission spectrometry. Toxicol. Environ. Chem. 75, 207, 2000.

29. MÜLLER G. Index of geoaccumulation in sediments of the Rhine River. Geojournal, 2, 108, 1969.

30. VEGA F.A., COVELO E.F., CERQUEIRA B., ANDRADE, M.L. Enrichment of marsh soils with heavy metals by effect of anthropic pollution. J. Hazard. Mater. 170, 1056, 2009.

31. LOSKAK., WIECHU A.D., KORUS I. Metal contamination of farming soils affected by industry. Environ. Int. 30, 159, 2004.

32. MÜLLER G. Die Schwermetallbelastung der sedimente des Neckars und seiner Nebenflusse: eine Bestandsaufnahme. Chemical Zeitung 105, 157, 1981.

33. HAKANSON L. Ecological risk index for aquatic pollution control. A sedimentological approach. Water Res. 14, 975, 1980

34. GUO W.H., LIU X.B., LIU Z.G., LI G.F. Pollution and potential ecological risk evaluation of heavy metals in the sediments around Dongjiang Harbor, Tianjin. Procedia Environ. Sci. 2, 729, 2010.

35. FU C., GUO J., PAN J., QI J., ZHOU W . Potential ecological risk assessment of heavy metal pollution in sediments of the Yangtze river within the wanzhou section, China. Biol. Trace Elem. Res. 129, 270, 2009.

36. BAO S.D., WANG R., YANG C. Soil and Agricultural Chemistry Analysis, third ed., Chinese Agricultural Press: Beijing, pp. 1-452, 1999 [In Chinese].

37. NABULO G., BLACK C.R., YOUNG S.D. Trace metal uptake by tropical vegetables grown on soil amended with urban sewage sludge. Environ. Pollut. 159, 368, 2011.

38. HUANG X.L., CHEN Y., SHENKER M. Dynamics of phosphorus phytoavailability in soil amended with stabilized sewage sludge materials. Geoderma 170, 144, 2012.
39. WANG H.L., WANG C.J., CHEN F., MA M.P., LIN Z.K. WANG W.W., XU Z.T., WANG X.D. Modification to degradation of hexazinone in forest soils amended with sewage sludge. J. Hazard. Mater. 199-200, 96, 2012.

40. CARBONELL G., PRO J., GÓMEZ N., BABÍN M.M., FERNÁNDEZ C., ALONSO E., TARAZONA J. V. Sewage sludge applied to agricultural soil: Ecotoxicological effects on representative soil organisms. Ecotox. Environ. Safe. 72, 1309, 2009.

41. TORRI S.I., LAVADO R. Zinc distribution in soils amended with different kinds of sewage sludge. J. Environ. Manage. 88, 1571, 2008.

42. ÁlVAREZ E.A, MOCHÓN M.C., SÁNCHEZ J.C.J., RODRÍGUEZ M.T. Heavy metal extractable forms in sludge from wastewater treatment plants. Chemosphere 47, 765, 2002.

43. ŠČANČAR J., MILAČIČ R., STRAŽAR M., BURICA O. Total metal concentrations and partitioning of $\mathrm{Cd}, \mathrm{Cr}, \mathrm{Cu}$, $\mathrm{Fe}, \mathrm{Ni}$ and $\mathrm{Zn}$ in sewage sludge. Sci. Total Environ. 250, 9, 2000.

44. FUENTES A., LLORÉNS M., SÁEZ J., SOLER A., AGUILAR M.I., ORTUÑO J.F., MESEGUER V.F. Simple and sequential extractions of heavy metals from different sewage sludges. Chemosphere 54, 1039, 2004.

45. MA X.W., WENG H.X., ZHANG J.J. Regional characteristrics and trend of heavy metals and nutrients of sewage sludges in China. China Environ. Sci. 31, 1306, 2011 [In Chinese].

46. MCGRATH S.P., CHANG A.C., PAGE A.L., WITTER E. Land application of sewage sludge: scientific perspectives of heavy metal loading limits in Europe and the United States. Environ. Rev. 2, 108, 1994

47. WONG C., LI X.D., ZHANG G., QI, S.H., MIN Y.S. Heavy metals in agricultural soils of the Pearl River Delta, South China. Environ. Pollut. 119, 33, 2002.

48. EPA(Environmental Protection Administration, PR China) . Ministry of Rural and Urban Construction PR China. Discharge standards of pollutants for municipal wastewater treatment plant (GB 18918-2002). 2002 [In Chinese].

49. WONG S. C., LI X.D., CHAN L. C. Removal of heavy metals from an aerobically digested sewage sludge by isolated indigenous iron oxidizing bacteria. Chemosphere 41, 283, 2000.

50. VEEKEN A.M., HAMELERS H.M. Removal of heavy metals from sewage sludge by extraction with organic acids. Water Sci. Technol. 40, 129, 1999.

51. EPA (Environment Protection Administration, PR China). Chinese Bulletin of Environment of 2000'. 2001 [In Chinese].

52. TENG Y.G., TUO X.G., NI S.J., ZHANG C.J. Assessment heavy metal pollution use geoaccumulation index in sediments: the background choice of geochemistry. Environ. Sci. Technol. 25, 7, 2002 [In Chinese].

53. RENOUX A.Y., TYAGI R.D., RÉJEAN S. Assessment of toxicity reduction after metal removal in bioleached sewage sludge. Water Res. 35, 1415, 2001.

54. DEEPULAL P.M., GIREESH K.T.R., SUJATHA C.H., GEORGE R. Chemometric study on the trace metal accumulation in the sediments of the Cochin Estuary Southwest coast of India. Environ. Monit. Assess. 184, 6261, 2012. 